\title{
Hummingbirds and the plants they visit in the Tehuacán-Cuicatlán Biosphere Reserve, Mexico
}

\section{Colibríes y las plantas que visitan en la Reseva de la Biosfera Tehuacán-Cuicatlán, México}

\author{
Raúl Ortiz-Pulido ${ }^{1,2 \otimes}$, S. Anaid Díaz ${ }^{1,3}$, Oscar I. Valle-Díaz ${ }^{1,4}$ and Ana D. Fisher ${ }^{1,5}$ \\ 1 Departamento de Quimica y Biología, Universidad de las Américas-Puebla, Ex hacienda Sta Catarina Mártir s/n, 72810 Cholula, Puebla, México. \\ ${ }^{2}$ Current address: Laboratorio de Ecología de Poblaciones, Centro de Investigaciones Biológicas, Universidad Autónoma del Estado de Hidalgo, \\ Apartado postal 69, 42001 Pachuca, Hidalgo, México. \\ ${ }^{3}$ Current address: School of Biological Sciences, University of Bristol, Woodland Road, Bristol, BS8 1UG, UK. \\ ${ }^{4}$ Current address: Club de aves Nycticorax, $2^{a}$ Cerrada de Mercurio \#13, Col. Jardines de Cuernavaca, 62360 Cuernavaca, Morelos, México. \\ ${ }^{5}$ Current address: Udall Center for Studies in Public Policy, University of Arizona. 803 East First St. Tucson, AZ 85719, USA. \\ 凶raulortizpulido@yahoo.com
}

\begin{abstract}
We describe the relative abundance, plant species visited, and plant communities used by hummingbird species inhabiting the Tehuacán-Cuicatlán Biosphere Reserve, a semiarid area in South-central Mexico. We recorded 14 hummingbird species and 35 plant species distributed in 4 plant communities during our study. We found 86 different hummingbird-plant interactions. Amazilia violiceps and Cynanthus latirostris were the most common hummingbirds, while $C$. latirostris, A violiceps, and Cynanthus sordidus were the hummingbirds that visited more plant species. Hummingbirds were distributed differentially between plant communities inside the reserve, with 12 species being present in the arboreal plant community of the lowlands, 11 both in cactus forest and perennial spine shrub plants, and 6 in perennial unarmed shrub plants. Cercidium praecox (Fabaceae) was the plant species with the highest number of visiting hummingbird species (10 species). Cactus forest and perennial spine shrub plants were the plant communities with largest number of possible interactions (57 and 51, respectively). The mean connectance value of the interaction matrix was similar between plant communities (near to $22 \%$ ), but lower than those reported previously in other places. In the Tehuacán-Cuicatlán Biosphere Reserve the hummingbird-plant interaction system will be preserved if the hummingbirds C. latirostris, A. violiceps, C. sordidus, and L. clemenciae, and the plants C. praecox, I. arborescens, E. chiotilla, and N. glauca, are protected.
\end{abstract}

Key words: hummingbird-plant interaction, Puebla-Oaxaca,Tehuacán-Cuicatlán Biosphere Reserve, ornithophilous flowers.

Resumen. Describimos la abundancia relativa, especies de plantas visitadas y tipos de vegetación utilizados por los colibríes de la Reserva de la Biosfera Tehuacán-Cuicatlán, México. Durante nuestro de estudio registramos 14 especies de colibríes y 35 especies de plantas utilizadas por ellos dentro de cuatro tipos de vegetación, representando 86 diferentes interacciones colibrí-planta. Amazilia violiceps y Cynanthus latirostris fueron los colibríes más comunes, mientras que $C$. latirostris, A. violiceps y Cynanthus sordidus fueron las especies que visitaron a un mayor número de especies de plantas. Los colibríes estuvieron distribuidos diferencialmente entre los tipos de vegetación, con 12 especies presentes en la comunidad de plantas arbóreas de tierras bajas, 11 tanto en los bosques de cactus como en la comunidad de plantas perennes arbustivas espinosas, y seis en la comunidad de plantas arbustivas perennes no espinosas. Cercidium praecox (Fabaceae) fue la especie con mayor número de especies de colibríes visitantes (10 especies). Las comunidades de bosque de cactus y plantas perennes arbustivas espinosas tuvieron los números más altos de posibles interacciones ( 57 y 51 , respectivamente). El valor de conectancia de las matrices de interacciones fue similar entre las cuatro comunidades de plantas (cercano al 22\%), pero más bajo que lo reportado previamente a nivel mundial. En la Reserva de la Biosfera Tehuacán-Cuicatlán el sistema de interacción colibrí-planta puede ser conservado si se protegen las especies de colibríes C. latirostris, A. violiceps, C. sordidus y L. clemenciae, y las de plantas $C$. praecox, I. arborescens, E. chiotilla y $N$. glauca.

Palabras clave: interacción colibrí-planta, Puebla-Oaxaca, Reserva de la Biosfera Tehuacán-Cuicatlán, flores ornitofílicas. 


\section{Introduction}

The distribution and ecology of hummingbird species inhabiting dry habitats are not fully understood (e.g. Ornelas and Arizmendi, 1995). Particularly, there is limited information regarding which plant species are used by these hummingbirds (but see Villada, 1873; Wolf, 1970; Baltosser, 1989; Arizmendi and Ornelas, 1990; Ornelas et al., 2002; Ortiz-Pulido and Vargas-Licona, 2008). A better understanding of hummingbird communities in semiarid zones can be useful in planning conservation strategies to maintain hummingbirds and the ecological services they provide, such as pollination. This is even more important under the conservation problems faced associated with land use change, and the different predictions of global warming scenarios (Sekercioglu et al., 2004; DiázValenzuela and Ortiz-Pulido, 2011), where we expect and increase in aridity in large areas of Mexico.

Currently, hummingbirds, as a group, are not considered endangered. However, changes in food availability and negative human effects, such as destruction of habitat, could threaten their survival (CITES, 2000; Sekercioglu et al., 2004). Data from Sekercioglu et al. (2004) suggests that, if the actual tendencies are maintained, $15 \%$ of the current hummingbird species could be extinct in the next century. Since many nectarivorous bird species affect plant populations and community dynamics, a reduction in their abundances could result in an increase in plant extinction risk. Thus, the extinction of nectarivorous birds may eliminate many established mutualisms between plants and birds (Sekercioglu et al., 2004).

A useful way to understand community hummingbirdplant interactions is to study the relationship through connectance and mutualistic networks. Connectance is a measure that helps to determine the relationship established in a community between 2 groups of species (Jordano, 1987). It has been used to describe patterns in several pollination systems around the world (e.g. Jordano, 1987). Mutualist networks are a way to represent, with graphs (drews) or equations, the established relationships between pairs of species in a community (e.g. Bascompte et al., 2006). Even though there are several studies where the connectance has been determined for hummingbirdplant systems, to the best of our knowledge, there is not a single study relating connectance and hummingbird-plant mutualistic networks of several plant communities located within a dry landscape.

The hummingbird species present in the TehuacánCuicatlán Biosphere Reserve (RBTC), Mexico, which is a semiarid region, along with the identity and seasonality of plants used by them throughout the year is only partially known (e.g., Ornelas et al., 2002; Arizmendi and
Valiente-Banuet, 2006). Different authors have published information on hummingbird and cactacean pollination from this region (hummingbirds: Arizmendi and Espinosa de los Monteros, 1996; Peterson et al., 2003; Arizmendi and Valiente-Banuet, 2006; Vázquez et al., 2009; cactacean: Valiente-Banuet et al., 1996, 1997; Casas et al., 1999; Ornelas et al., 2002; Otero-Arnaiz et al., 2003; OaxacaVilla et al., 2006). These studies report the presence of 9 hummingbird species (Cynanthus sordidus, C. latirostris, Amazilia violiceps, Lampornis clemenciae, Eugenes fulgens, Calothorax lucifer, C. pulcher, Archilochus colubris, and Atthis eloisa) in 3 of the 6 plant communities present in the RBTC (called plant groups by ValienteBanuet et al., 2000). However, a review of the literature of the birds of Mexico and Central America (Howell and Webb, 1995) and the RBTC surrounding areas (Binford, 1989; Forcey, 2002) suggest the existence of 12-14 species in the RBTC. Besides, it is unknown the connectance values that exist for the hummingbird-plant mutualistic networks in this important arid region of Mexico.

In this study, we describe hummingbird species richness and the plants they visit in 4 plant communities of the RBTC. Our objectives are: 1) to describe how hummingbirds use these 4 plant communities, 2) to report the plant species visited by them in this semiarid zone of central Mexico, and (c) to describe the hummingbird-plant mutualist networks of this region, by using the conectance value and mutualistic network graphs.

\section{Material and methods}

The RBTC is located in the States of Puebla and Oaxaca in central Mexico $\left(17^{\circ} 48^{\prime}-18^{\circ} 56^{\prime} \mathrm{N}, 97^{\circ} 03^{\prime}-97^{\circ} 43^{\prime} \mathrm{W}\right.$, 545-2 950 m asl; INE, 1999; Fig. 1). It is a large reserve (490 $186 \mathrm{ha}$ ), that mainly protects semiarid habitats (Gobierno de Mexico, 1998). More than 2750 plant species had been described in the area and nearly $30 \%$ of them are endemic to the RBTC (Villaseñor et al., 1990).

The vegetation diversity present within the RBTC has been systematized into 6 plant communities ("plant groups" sensu Valiente-Banuet et al., 2000): cactus forest (CF), arboreal plants of the lowlands (APLL; $<2100 \mathrm{~m}$ asl), perennial spine shrub plants (PSSP), perennial non-spiny (unarmed) shrub plants (PUSP), arboreal plants and shrubs associated with perennial rivers (ASPR), and arboreal plants of the highlands (APHL). Details on the plant communities can be reviewed in Arriaga et al. (2000) and Valiente-Banuet et al. (2000). For our study, we only considered plant communities with a climate that can be described mainly as semiarid (CF, APLL, PSSP and PUSP; INEGI, 1998a).

Fieldwork was conducted from February 2001 to February 2002 at 14 sites (Fig. 1). All sites were selected 


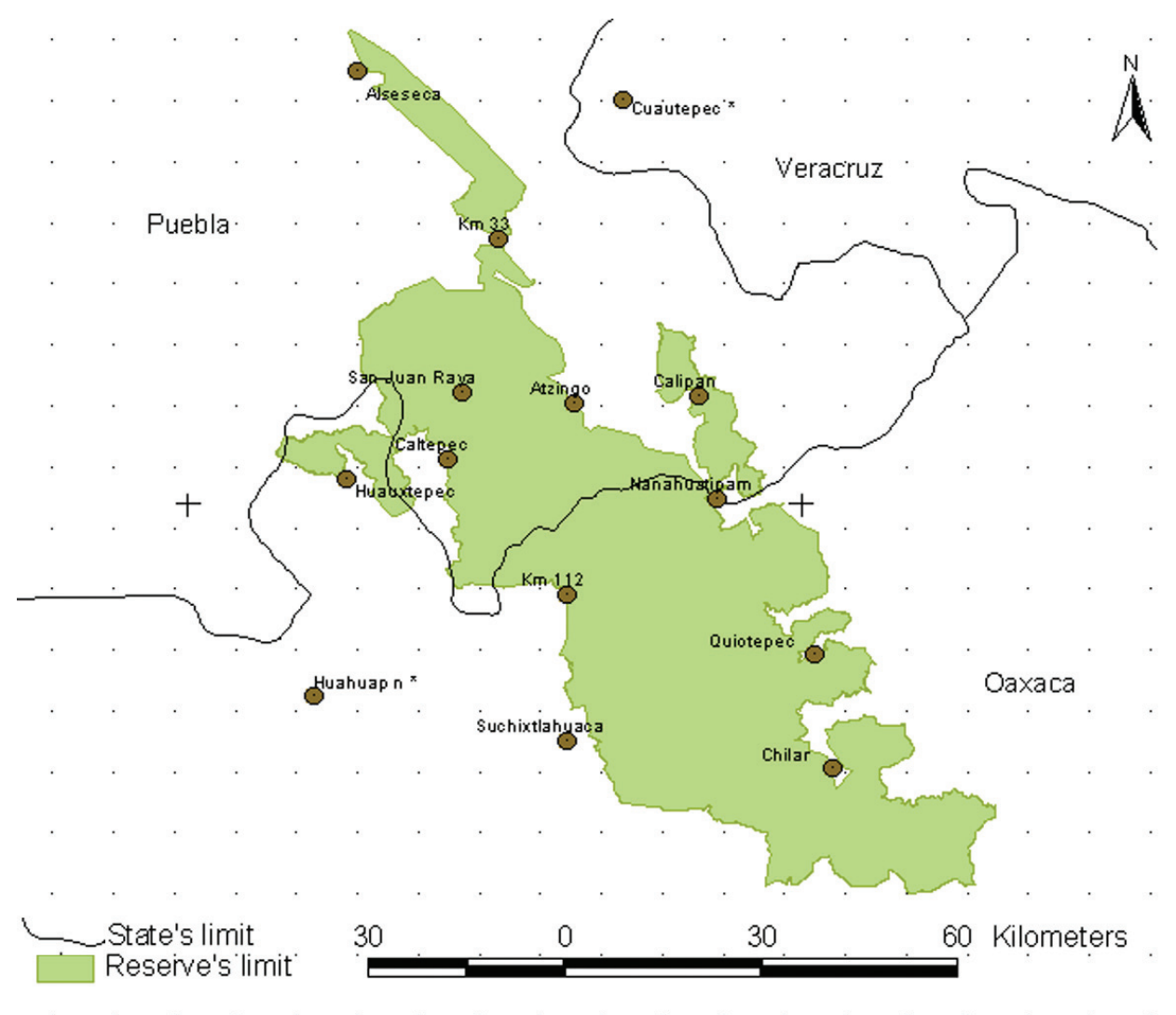

Figure 1. Sites monitored in or near to the Tehuacán-Cuicatlán Biosphere Reserve in Mexico. Small circles mark sites visited during this study.

randomly from a pool of accessible sites of each of the plant communities using a map (scale 1:250,000; INEGI, $1998 \mathrm{~b})$ and a table of random numbers. All the sites were $\geq 15 \mathrm{~km}$ apart. Four sites were sampled from each plant community, except for PUSP, which had only 2 sampling sites. It was not possible to reach more sites of this plant community due to inaccessibility problems in the field. The name of each site, location, altitude, and dominant plant association are listed in Table 1. Plant communities and dominant plant species were determined following Valiente-Banuet et al. (2000). Each site was sampled monthly or bimonthly due to weather conditions, combined with rough topography, and lack of roads, affected the access to some of the sites during some seasons or months.

To identify hummingbird species and determine their relative abundances, a technique described by Emlen (1971) was followed, and it was modified by OrtizPulido and Diaz (2001). Briefly, one observer counted hummingbirds along a $2 \mathrm{~km} \times 40 \mathrm{~m}$ transect at a rate of $1 \mathrm{~km} / \mathrm{hr}$ at each site, paying particular attention to flower clusters with ornithophilus characteristics (tube shape and bright colors; Johnsgard, 1997). Transects at each site were established using existing animal or human paths. Three different observers (ROP, OIVI, and ADFL) identified the hummingbirds during this study, recording only visual sightings of hummingbirds that visited flowers or were observed perched inside the transects area. Observers standardized their hummingbird field identification abilities by conducting 3 months of training previous to the study. Due to the difficulties of identifying females in the field, we report only hummingbird species for which males were observed. Transects were sampled within $6 \mathrm{hrs}$ of sunrise. We registered monthly information on hummingbird species and the number of individuals. Occasionally, we used mist nets, to capture secretive species. The names of the species reported follows the American Ornithologists' Union Checklist (1998) and posterior modifications (American Ornithologists' Union, 2009). Hummingbird relative abundance (taking into account only visual records) was estimated following Ortiz-Pulido et al. (2010) methods. Briefly, we adjusted the fieldwork effort (170 hrs of sampling effort in the transects) to a standardized sampling effort (SSE), which takes into account $100 \mathrm{hrs}$ of observation or 400 ha 
Table 1. Characteristics of the 14 sites sampled in the RBTC, México

\begin{tabular}{|c|c|c|c|c|c|}
\hline Site & $\begin{array}{l}\text { Altitude } \\
\text { (m asl) }\end{array}$ & $\begin{array}{l}\text { Plant } \\
\text { community }^{l}\end{array}$ & $\begin{array}{c}\text { Dominant plant association } \\
\text { (sensu Valiente-Banuet et al., 2000) }\end{array}$ & $\begin{array}{c}\text { Mean annual } \\
\text { precipitation }(\mathrm{mm})\end{array}$ & $\begin{array}{c}\text { Mean annual } \\
\text { temperature }\left({ }^{\circ} \mathrm{C}\right)\end{array}$ \\
\hline Chilar & 660 & $\mathrm{CF}$ & Escontria chiotilla Jiotillal & $400-500$ & $22-24$ \\
\hline Quiotepec & 630 & $\mathrm{CF}$ & Pachycereus weberi Cardonal & $400-500$ & $22-24$ \\
\hline Nanahuatipam & 810 & PSSP & Shrubs with lateral thorns & $300-400$ & $26-28$ \\
\hline Calipan & 1200 & $\mathrm{CF}$ & Pachycereus weberi Cardonal & $400-500$ & $22-24$ \\
\hline Atzingo & 1260 & PSSP & Shrubs with lateral thorns & $400-500$ & $20-22$ \\
\hline San Juan Raya & 1560 & PSSP & Shrubs with lateral thorns & $600-700$ & $18-20$ \\
\hline $\mathrm{Km} 33$ & 1745 & APLL & Izotal $^{2}$ & $400-500$ & $18-20$ \\
\hline Huauxtepec & 1800 & $\mathrm{CF}$ & Escontria chiotilla Jiotillal & $700-800$ & $16-18$ \\
\hline Suchixtlahuaca & 2010 & PUSP & Perennifolial sclerophilous shrubs (mexical) & $600-700$ & $20-22$ \\
\hline $\mathrm{Km} 112$ & 2040 & PUSP & Perennifolial sclerophilous shrubs (mexical) & $400-500$ & $22-24$ \\
\hline Alseseca & 2100 & APLL & Izotal $^{2}$ & $400-500$ & $16-18$ \\
\hline Caltepec & 2190 & PSSP & Shrubs with lateral thorns & $400-500$ & $18-20$ \\
\hline Cuautepec * & 1900 & APLL & Tropical dry forest & $500-600$ & $18-20$ \\
\hline Huajuapán * & 1600 & APLL & Tropical dry forest & $600-700$ & $18-20$ \\
\hline
\end{tabular}

${ }^{1} \ll$ Plant group» sensu Valiente-Banuet et al. 2000. CF $=$ cactus forest, APLL= arboreal plants of the lowlands, PSSP $=$ perennial spine shrub plants, and PUSP $=$ perennial unarmed shrub plants. *Places visited only one time.

${ }^{2}$ Valiente-Banuet et al. (2000) reported a dominant species in this type of plant community, but the site sampled was located in a perturbed area, so we could not determine a dominant plant species.

sampled. Following this criteria, species where classified as: rare if they were recorded $<3.5$ times per SSE, common if they were recorded between 3.5 to 21.9 times at SSE, and abundant if they were recorded $>22$ times at SSE. The limit values between abundance categories used here (i.e. 3.5 and 21.9 records) reflect the common abundance distribution of the species in communities (Tokeshi, 1993; Begon et al., 2006); this distribution appears when the the percentage of rare, common, and abundant species in bird communities is considered (see details in Ortiz-Pulido et al., 2010).

Using the hummingbird records per species per site, the expected RBTC hummingbird richness with the program Estimates (Colwell, 2005) was determined. To do this we used Chao 2 and $1^{\text {st }}$ order Jacknife richness index. These indexes had been suggested as good estimators of species richness in several global reviews (Colwell and Coddington, 1994; Walther and Morand, 1998; Walther and Moore, 2005).

Additionally, to document the highest number of hummingbird-plant interactions we conducted focal observations of flowering plants. Focal observations on plants species were done monthly in every site sampled, with at least $1 \mathrm{hr}$ of observation on groups of flowering plants per site ( $\mathrm{n}=14$ sites), so a plant species located in several sites by several months had more time of observation than a plant located in only 1 site 1 month.

The distribution of hummingbirds species in each plant community was assessed by taking into account our data, and literature reports of previous studies conducted in the
RBTC (Arizmendi and Espinosa de los Monteros, 1996; Valiente-Banuet et al., 1996, 1997; Casas et al., 1999; Ornelas et al., 2002; Otero-Arnaiz et al., 2003; Peterson et al., 2003; Arizmendi and Valiente-Banuet, 2006; Oaxaca-Villa et al., 2006; Vázquez et al., 2009). We did not consider studies outside the RBTC (e.g. Forcey, 2002; Grosselet and Burcsu, 2005), or those conducted inside the reserve in plant communities not considered in this study (e.g. Binford, 1989).

At each site, we collected herbarium specimens of the flowering plants visited by hummingbirds, and recorded the corolla color, one of the main signals used to select flowers by hummingbirds (Johnsgard, 1997). All the plant specimens were deposited in the herbarium of the Universidad de las Americas-Puebla. Scientific names of plant species follow nomenclature established by the nomenclatural data base VAST (Missouri Botanical Garden, 2005). We only considered plant species in which we registered hummingbird visits. We consider a "visit" when a hummingbird introduced its bill into the flower. Plant visits were recorded both during our visits along the transects, or during focal observations.

Using transect and focal observations we built a qualitative interaction matrix (sensu Jordano, 1987), where, for the entire reserve, the identity of a pair of interacting species was indicated. We extrapolated the information contained in this interaction matrix to every plant community studied. In this way we calculated the connectance value (C) and elaborated the interaction mutualistic network (graphs) by plant community. 
Table 2. Relative abundance of hummingbirds per plant community, as defined in Table 1, in the Tehuacán-Cuicatlán Biosphere Reserve, Mexico, at 2001-2002

\begin{tabular}{|c|c|c|c|c|c|c|}
\hline \multirow[t]{2}{*}{ Species } & \multirow[t]{2}{*}{ Relative abundance } & \multicolumn{5}{|c|}{ Records } \\
\hline & & Total & $C F$ & $A P L L$ & PSSP & PUSP \\
\hline Colibri thalassinus* & Rare & 1 & & & & 1 \\
\hline Cynanthus sordidus & Common & 22 & 3 & \# & 17 & 2 \\
\hline Cynanthus latirostris & Common & 27 & 4 & 4 & 19 & \\
\hline Hylocharis leucotis & Rare & 5 & 2 & 2 & 1 & \\
\hline Amazilia tzacatl & Commom & 11 & 1 & 3 & & 7 \\
\hline Amazilia violiceps & Abundant & 37 & 6 & 5 & 8 & 18 \\
\hline Amazilia viridifrons & Common & 16 & 2 & 1 & 3 & 10 \\
\hline Eugenes fulgens & Common & 15 & 8 & 5 & \# & 2 \\
\hline Lampornis clemenciae & Common & 15 & 5 & 1 & 9 & \\
\hline Calothorax sp. (C. lucifer + C.pulcher) & Common & 14 & & 4 & 10 & \\
\hline Calothorax lucifer & & & \# & $\mathrm{R}$ & \# & \\
\hline Calothorax pulcher & & & \# & $\mathrm{R}^{\#}$ & $\mathrm{R}^{\#}$ & \\
\hline Archilochus colubris & Rare & 3 & 1 & \# & 2 & \\
\hline Atthis eloisa \# & & & & \# & & \\
\hline Selasphorus platycercus & Rare & 4 & & & 4 & \\
\hline
\end{tabular}

*= Species captured in mist nests; R species sighted; ${ }^{*}=$ species reported by other authors (Valiente-Banuet et al., 1996, 1997; Casas et al., 1999; Ornelas et al., 2002; Otero-Arnaiz et al., 2003).

Connectance value is defined as $\mathrm{C}=100 \mathrm{xI} /(\mathrm{AxP})$, where I is the total number of interactions recorded by plant community, and $\mathrm{A}$ and $\mathrm{P}$ is the number of animals and plant species recorded by plant community (sensu Jordano, 1987). The graphs were constructed taking into account the hummingbirds and plants species present in each plant community.

\section{Results}

We recorded 12 species of hummingbirds (Cynanthus sordidus, C. latirostris, Hylocharis leucotis, Amazilia tzacatl, A. violiceps, A. viridifrons, Lampornis clemenciae, Eugenes fulgens, Calothorax lucifer, C. pulcher, Archilocus colubris, and Selasphorus platycercus) in a total of 170 hummingbird sightings within the transects. One more species (Colibri thalassinus) was captured using mist-nets, and another one (Atthis eloisa) was reported by another study (Table 2). Using the data from the transects, the total expected number of hummingbirds species for the RBTC was $12.5 \pm 1.2($ mean $\pm 1 \mathrm{sd}$; Chao2 index) or $13.8 \pm 1.2$ (Jacknife index). This indicates that our study represents a good sampling effort of the study area. The species with the highest number of records were A. violiceps (37) and C. latirostris (27) (Table 2); and the ones with the least number of observations were $A$. colubris, $S$. platycercus, and H. leucotis.

When we added literature records to our dataset (Table 3 ) we detected that 12 hummingbird species are reported for the APLL, 11 both in both CF and PSSP communities, and 6 in the PUSP community (Table 2). Cynanthus sordidus, A. violiceps, A. viridifrons, and E. fulgens are distributed in the 4 plant communities studied, while $C$. thalassinus, A. eloisa, and S. platycercus were present in only one of them (Table 3 ).

We recorded 32 plant species visited by hummingbirds; additionally 3 other plant species were reported by other authors (Table 4). These species represented 21 genera, distributed in 14 families. The family with the highest number of species recorded was Cactaceae (16 species); 9 families were represented by only 1 species (Table 4). The predominant color among flowers was yellow (11 species), followed by white and pink (8 each), purple and red ( 3 each), and orange ( 2 ; table 4$)$. After adding literature records to our results we had a total of 25 plant species to be visited by hummingbirds in CF, 24 in PSSP, 10 in APLL, and 5 in PUSP (Table 4). We recorded 2 species (Tecoma stans and Opuntia hyptiacantha) distributed in the 4 plant communities studied, and 7 species (Prosopis juliflora, Ipomoea arborescens, Salvia sp. 1, Nicotina glauca, Opuntia huajuapensis, O. pilifera, and Stenocereus stellatus) distributed in 3 plant communities (Table 4).

We registered 62 different hummingbird-plant species interactions for which we could identify both species, 10 more interactions where only identified to the plant species, and 14 more interactions were from the literature (Table 5). The hummingbird species that visited the most plant species were C. latirostris (18 plant species visited), $A$. violiceps (15), and C. sordidus (11). The hummingbird species that were recorded visiting the smallest number of plant species were Archilochus colubris and C. lucifer (one each; Table 5). We did not record $C$. thalassinus and $A$. 
Table 3. Hummingbird records per plant community and vegetation type. Data are from studies done in the Tehuacán-Cuicatlán Biosphere Reserve, Oaxaca-Puebla, Mexico, reported from 1996 to 2010

\begin{tabular}{|c|c|c|c|c|c|c|c|c|c|c|c|c|c|c|c|c|}
\hline \multirow[t]{2}{*}{ Reference } & & \multicolumn{2}{|c|}{ Vegetation studied $*$} & \multicolumn{13}{|c|}{ Hummingbird species recorded ${ }^{\#}$} \\
\hline & & Plant community & $\begin{array}{c}\text { Vegetation type } \\
\text { (or name used in each study) }\end{array}$ & 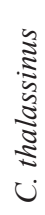 & $\begin{array}{l}\frac{3}{3} \\
\frac{3}{0} \\
\vdots \\
0 \\
0 \\
ن\end{array}$ & 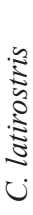 & 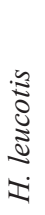 & $\begin{array}{l}\widetilde{Z} \\
\tilde{Z} \\
\mathbb{N} \\
-1\end{array}$ & & & 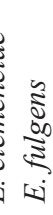 & 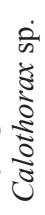 & 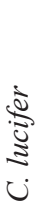 & ن. & & 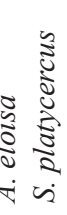 \\
\hline \multirow{4}{*}{$\begin{array}{l}\text { Arizmendi and } \\
\text { Espinosa de los } \\
\text { Monteros }\end{array}$} & 1996 & Cactus forest & N. tetetzo Tetechera & & $\mathrm{x}$ & $\mathrm{x}$ & & & $\mathrm{x}$ & & & & $\mathrm{x}$ & $\mathrm{x}$ & $\mathrm{x}$ & \\
\hline & & & C. hoppenstedtii Cardonal & & & & & & & & & & & & & \\
\hline & & & $\begin{array}{l}\text { N. mezcalaensis y } N . \\
\text { macrocephala Tetechera }\end{array}$ & & $\mathrm{x}$ & $\mathrm{x}$ & & & $\mathrm{x}$ & & & & $\mathrm{x}$ & $\mathrm{x}$ & $\mathrm{x}$ & \\
\hline & & $\begin{array}{l}\text { Arboreal plants } \\
\text { of the lowlands }\end{array}$ & Y. periculosa Izotal & & $\mathrm{x}$ & $\mathrm{x}$ & & & $\mathrm{x}$ & & & & $\mathrm{x}$ & $\mathrm{x}$ & & \\
\hline Valiente-Banuet et al. & 1996 & Cactus forest & N. tetetzo Tetechera & & $\mathrm{x}$ & & & & $\mathrm{x}$ & & & & & & & \\
\hline \multirow[t]{2}{*}{ Valiente-Banuet et al. } & 1997 & Cactus forest & P. weberi Cardonal & & & $\mathrm{x}$ & & & & & & & & & & \\
\hline & & $\begin{array}{l}\text { Perennial spine } \\
\text { shrub plants?** }\end{array}$ & Xerophile shrubs & & & $\mathrm{x}$ & & & & & & & & & & \\
\hline Casas et al. & 1999 & Cactus forest & S. stellatus Cardonal & & $\mathrm{x}$ & $\mathrm{x}$ & & & $\mathrm{x}$ & & & & & & & \\
\hline Ornelas et al. & 2002 & $\begin{array}{l}\text { Perennial spine } \\
\text { shrub plants?** }\end{array}$ & Xerophile shrubs & & $\mathrm{x}$ & $\mathrm{x}$ & & & $\mathrm{x}$ & $\mathrm{x}$ & $\mathrm{x}$ & & $\mathrm{x}$ & & & \\
\hline \multirow[t]{2}{*}{ Peterson et al. } & 2003 & Cactus forest & $\begin{array}{l}\text { In a community called "El } \\
\text { Venado" }\end{array}$ & & $\mathrm{x}$ & $\mathrm{x}$ & & & $\mathrm{x}$ & & & & & & & \\
\hline & & $\begin{array}{l}\text { Arboreal plants } \\
\text { of the lowlands }\end{array}$ & $\begin{array}{l}\text { In a place called "La } \\
\text { cañada" }\end{array}$ & & $\mathrm{x}$ & $\mathrm{x}$ & & & $\mathrm{x}$ & & & & & & & \\
\hline Otero-Arnaiz et al. & 2003 & Cactus forest & P. chichipe Chichipera & & $\mathrm{x}$ & $\mathrm{x}$ & & & $\mathrm{x}$ & & & & & & & \\
\hline Oaxaca-Villa et al. & 2006 & Cactus forest & E. chiotilla Jiotillal & & $\mathrm{x}$ & $\mathrm{x}$ & & & $\mathrm{x}$ & & & & & & & \\
\hline \multirow{5}{*}{$\begin{array}{l}\text { Arizmendi and } \\
\text { Valiente-Banuet }\end{array}$} & 2006 & Cactus forest & Cactus forest & & & $\mathrm{x}$ & & & & & & & & $\mathrm{x}$ & $\mathrm{x}$ & \\
\hline & & Arboreal plants & Izotal & & $\mathrm{x}$ & $\mathrm{x}$ & & & & & & & $\mathrm{x}$ & $\mathrm{x}$ & & \\
\hline & & & Dry forest & & $\mathrm{x}$ & $\mathrm{x}$ & & & & & & & & & & \\
\hline & & & Perennial thorned dry forest & & $\mathrm{x}$ & $\mathrm{x}$ & & & & & & & & $\mathrm{x}$ & & \\
\hline & & $\begin{array}{l}\text { Perennial spine } \\
\text { shrub plants }\end{array}$ & $\begin{array}{l}\text { Perennifolial sclerophilous } \\
\text { shrubs (Mexical) }\end{array}$ & & & $\mathrm{x}$ & & & & & $\mathrm{x}$ & & & $\mathrm{x}$ & & \\
\hline $\begin{array}{l}\text { Vázquez et al. (sensu } \\
\text { Apéndice 1) }\end{array}$ & 2009 & $\begin{array}{l}\text { Arboreal plants } \\
\text { of the lowlands }\end{array}$ & Tropical dry forest & & $\mathrm{x}$ & $\mathrm{x}$ & & & $\mathrm{x}$ & $\mathrm{x}$ & & $\mathrm{x}$ & & & $\mathrm{x} \quad \mathrm{x}$ & $\mathrm{x}$ \\
\hline \multirow[t]{6}{*}{ Current study } & 2012 & Cactus forest & E. chiotilla Jiotillal & & $\mathrm{x}$ & $\mathrm{x}$ & $\mathrm{x}$ & & $x \quad x$ & $x \quad x$ & $x$ & & & & & \\
\hline & & & P. weberi Cardonal & & $\mathrm{x}$ & $\mathrm{x}$ & & $\mathrm{x}$ & $\mathrm{x}$ & $\mathrm{x}$ & $x$ & & & & $\mathrm{x}$ & \\
\hline & & $\begin{array}{l}\text { Arboreal plants } \\
\text { of the lowlands }\end{array}$ & Izotal & & $?$ & $\mathrm{x}$ & $\mathrm{x}$ & $\mathrm{x}$ & $\mathrm{x}$ & $x \quad x$ & $x$ & $\mathrm{x}$ & $\mathrm{x}$ & $\mathrm{x}$ & & \\
\hline & & Perennial spine & Shrubs with lateral thorns & & $\mathrm{x}$ & $\mathrm{x}$ & $\mathrm{x}$ & & $\mathrm{x}$ & $x \quad x$ & ? & $\mathrm{x}$ & & $\mathrm{x}$ & $\mathrm{x}$ & $\mathrm{x}$ \\
\hline & & sintu & Tropical dry forest & & & $\mathrm{x}$ & $\mathrm{x}$ & $?$ & $x \quad x$ & $\mathrm{x}$ & $?$ & $\mathrm{x}$ & & & & \\
\hline & & $\begin{array}{l}\text { Perennial } \\
\text { unarmed shrub } \\
\text { plants }\end{array}$ & $\begin{array}{l}\text { Perennifolial sclerophilous } \\
\text { shrubs (Mexical) }\end{array}$ & $\mathrm{x}$ & $\mathrm{x}$ & & & $\mathrm{x}$ & $\mathrm{x} \quad \mathrm{x}$ & $\mathrm{x}$ & $\mathrm{x}$ & & & & & \\
\hline
\end{tabular}

*Sensu Valiente-Banuet et al. (2000). We did not take into account man-made vegetation types (e.g., cultivations, urban areas), riparian o aquatic vegetation; as those described in Arizmendi and Valiente-Banuet (2006).

**It is not very clear to which plant community the authors refer.

${ }^{\#} \mathrm{x}=$ recorded in the plant community and vegetation type, ?= doubts about the record. 
Table 4. Plant species whose flowers are visited by hummingbirds in the RBTC, México

\begin{tabular}{|c|c|c|c|c|c|c|}
\hline \multirow[t]{2}{*}{ Family } & \multirow[t]{2}{*}{ Species } & \multirow[t]{2}{*}{ Corolla color } & \multicolumn{4}{|c|}{ Plant community } \\
\hline & & & $C F$ & $A P L L$ & PSSP & PUSP \\
\hline \multirow[t]{2}{*}{ Acanthaceae } & Acanthaceae sp. 1 & Red & & & $\mathrm{X}$ & \\
\hline & Acanthaceae sp. 2 & Orange & & & $\mathrm{X}$ & \\
\hline \multirow[t]{3}{*}{ Agavaceae } & Agave marmorata & Yellow & & & \# & \\
\hline & Agave sp. 1 & Yellow & & & $\mathrm{X}$ & \\
\hline & Agave sp. 2 & Yellow & & & $\mathrm{X}$ & \\
\hline Bignoniaceae & Tecoma stans & Yellow & $\mathrm{X}$ & $\mathrm{X}$ & $\mathrm{X}$ & $\mathrm{X}$ \\
\hline Bombacaceae & Ceiba parvifolia & White & $\mathrm{X}$ & & & \\
\hline Bromeliaceae & Tillandsia dugesii & Pink & & & $\mathrm{X}$ & \\
\hline \multirow[t]{16}{*}{ Cactaceae } & Escontria chiotilla & Yellow & $\mathrm{X}$ & & $\mathrm{X}$ & \\
\hline & Myrtillocactus geometrizans & White & $\mathrm{X}$ & & $\mathrm{X}$ & \\
\hline & Neobuxbaumia tetetzo ${ }^{\#}$ & White & \# & & & \\
\hline & Opuntia decumbens & Yellow & & $\mathrm{X}$ & $\mathrm{X}$ & \\
\hline & Opuntia depressa & Pink & $\mathrm{X}$ & & $\mathrm{X}$ & \\
\hline & Opuntia huajuapensis & Yellow & $\mathrm{X}$ & $\mathrm{X}$ & $\mathrm{X}$ & \\
\hline & Opuntia hyptiacantha & $\begin{array}{l}\text { Orange- } \\
\text { Yellow }\end{array}$ & $\mathrm{X}$ & $\mathrm{X}$ & $\mathrm{X}$ & $\mathrm{X}$ \\
\hline & Opuntia kleiniae & Yellow & & & $\mathrm{X}$ & \\
\hline & Opuntia pilifera & Pink & $\mathrm{X}$ & $\mathrm{X}$ & $\mathrm{X}$ & \\
\hline & Opuntia tehuacana & Pink & $\mathrm{X}$ & & $\mathrm{X}$ & \\
\hline & Opuntia velutina & Yellow & $\mathrm{X}$ & & & \\
\hline & Pachycereus weberi & White & $\mathrm{X}$ & & & \\
\hline & Pilosocereus chrysacanthus ${ }^{\#}$ & Pink & \# & & & \\
\hline & Polaskia chichipe & White & & $\mathrm{X}$ & & \\
\hline & Stenocereus pruinosus & Pink & $\mathrm{X}$ & & $\mathrm{X}$ & \\
\hline & Stenocereus stellatus & Pink & $\mathrm{X}$ & $\mathrm{X}$ & $\mathrm{X}$ & \\
\hline \multirow[t]{2}{*}{ Convolvulaceae } & Ipomoea arborescens & White & $\mathrm{X}$ & $\mathrm{X}$ & $\mathrm{X}$ & \\
\hline & Ipomoea sp. 1 & Pink & $\mathrm{X}$ & & $\mathrm{X}$ & \\
\hline Euphorbiaceae & Cnidoscolus multilobus & Yellow & $\mathrm{X}$ & & & \\
\hline Fabaceae & Cercidium praecox & White & $\mathrm{X}$ & & $\mathrm{X}$ & \\
\hline Fouquieriaceae & Fouquieria formosa & Red & $\mathrm{X}$ & & $\mathrm{X}$ & \\
\hline Hydrophyllaceae & Wigandia urens & Purple & $\mathrm{X}$ & & & \\
\hline \multirow[t]{3}{*}{ Lamiaceae } & Salvia sp. 1 & Purple & $\mathrm{X}$ & & $\mathrm{X}$ & $\mathrm{X}$ \\
\hline & Salvia sp. 2 & Purple & & & & $\mathrm{X}$ \\
\hline & Labiada sp. 1 & Red & $\mathrm{X}$ & & & \\
\hline Mimosaceae & Prosopis juliflora & White & $\mathrm{X}$ & $\mathrm{X}$ & $\mathrm{X}$ & \\
\hline Solanaceae & Nicotiana glauca & Yellow & $\mathrm{X}$ & $\mathrm{X}$ & & $\mathrm{X}$ \\
\hline
\end{tabular}

“\#” indicates species reported by other authors (i.e., Valiente-Banuet et al., 1996, 1997; Ornelas et al., 2002).

eloisa visiting any plants. Cercidium praecox (Fabaceae) was the plant species that received the most visits from more hummingbird species (10 hummingbird species visiting; Table 5), while 8 plant species were only visited by 1 hummingbird species: Ipomoea sp. 1 (Convolvulaceae), Pachycereus weberi, Pilosocereus chrysacanthus, Opuntia tehuacana, O. velutina (all Cactaceae), Tecoma stans (Bignoniaceae), Salvia sp. 2 and Ceiba parvifolia (Bombacaceae).

CF and PSSP were the plant communities with largest number of possible interactions (57 and 51, respectively), followed for APLL (28) and PUSP (7) (Fig. 2). The more complex interaction graphs are those from CF and PSSP and the lesser from PUSP. The connectance value is similar between plant communities, with $19.1 \%$ for PSSP, $20.7 \%$ for CF, $21.2 \%$ for APLL, and $26.7 \%$ for APLL.

\section{Discussion}

Our study shows that in the semiarid plant communities of the RBTC: (a), there are 14 hummingbird species; (b) 35 , plant species are visited by hummingbirds; (c), both species groups have a differential distribution across plant communities; (d), we detected nearly 86 different hummingbird-plant interactions; (e), the interactions are distributed differentially between plant communities, 
Table 5. Interaction matrix between hummingbird and plant species in the RBTC, México. " $X$ " indicates that we registered the interaction between the hummingbird (column) and the plant species (row). "*” indicates that we registered hummingbirds visiting these plant species, but we did not identify the visiting species. "\#” indicates species or interaction reported by other authors (ValienteBanuet et al., 1996, 1997; Casas et al., 1999; Ornelas et al., 2002; Otero-Arnaiz et al., 2003)

\begin{tabular}{|c|c|c|c|c|c|c|c|c|c|c|c|c|c|c|c|c|}
\hline Plants & 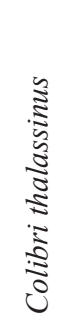 & 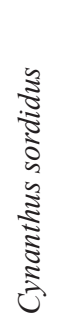 & 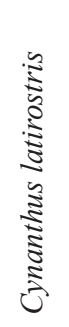 & 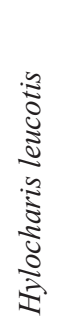 & 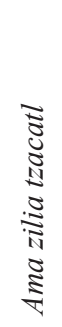 & 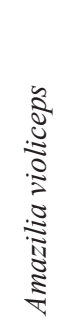 & 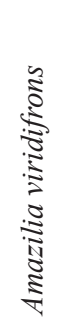 & 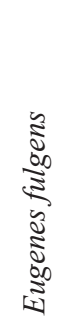 & 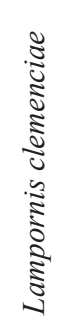 & 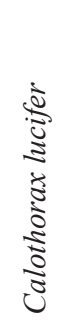 & 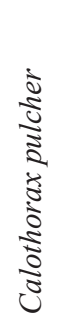 & 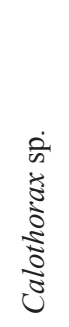 & 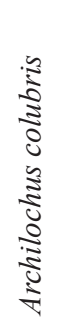 & 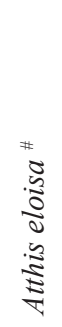 & 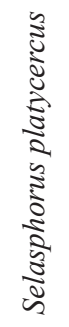 & $\bar{\Xi}$ \\
\hline Acanthaceae sp. 1 & & & $\mathrm{X}$ & & & & & & $\mathrm{X}$ & & & & & & & 2 \\
\hline Acanthaceae sp. 2 & & & $\mathrm{X}$ & & & & & & $\mathrm{X}$ & & & & & & & 2 \\
\hline Agave marmorata ${ }^{\#}$ & & & $\#$ & & & $\#$ & & $\#$ & $\#$ & & $\#$ & & & & & 5 \\
\hline Agave sp. 1 & & & & & & $\mathrm{X}$ & & & & & & $\mathrm{X}$ & & & & 2 \\
\hline Agave sp. 2 & & & & & & & & & & & & & & & & $*$ \\
\hline Ceiba parvifolia & & & & & & $\mathrm{X}$ & & & & & & & & & & 1 \\
\hline Cercidium praecox & & $\mathrm{X}$ & $\mathrm{X}$ & $\mathrm{X}$ & $\mathrm{X}$ & $\mathrm{X}$ & & $\mathrm{X}$ & $\mathrm{X}$ & & $\mathrm{X}$ & $\mathrm{X}$ & & & $\mathrm{X}$ & 10 \\
\hline Cnidoscolus multilobus & & $\mathrm{X}$ & $\mathrm{X}$ & & & & & & & & & & & & & 2 \\
\hline Escontria chiotilla & & $\mathrm{X}$ & $\mathrm{X}$ & $\mathrm{X}$ & & $\mathrm{X}$ & $\mathrm{X}$ & & & & & & & & & 5 \\
\hline Fouquieria formosa & & & & & & & & & & & & & & & & $*$ \\
\hline Ipomoea arborescens & & $\mathrm{X}$ & $\mathrm{X}$ & & & & & $\mathrm{X}$ & $\mathrm{X}$ & $\mathrm{X}$ & $\mathrm{X}$ & & & & & 6 \\
\hline Ipomoea $\mathrm{sp} 1$ & & & $\mathrm{X}$ & & & & & & & & & & & & & 1 \\
\hline Labiada sp. 1 & & & & & & & $\mathrm{X}$ & $\mathrm{X}$ & $\mathrm{X}$ & & & & & & & 3 \\
\hline Myrtillocactus geometrizans & & $\mathrm{X}$ & & & & & & & & & $\mathrm{X}$ & & & & & 2 \\
\hline Neobuxbaumia tetetzo ${ }^{\#}$ & & \# & & & & $\#$ & & & & & & & & & & 2 \\
\hline Nicotiana glauca & & $\mathrm{X}$ & & & $\mathrm{X}$ & $\mathrm{X}$ & $\mathrm{X}$ & $\mathrm{X}$ & & & & & & & $\mathrm{X}$ & 6 \\
\hline Pachycereus weberi & & & $\#$ & & & & & & & & & & & & & $1^{*}$ \\
\hline Pilosocereus chrysacanthus ${ }^{\#}$ & & & $\#$ & & & & & & & & & & & & & 1 \\
\hline Prosopis juliflora & & & $\mathrm{X}$ & & & & & & & & & $\mathrm{X}$ & & & & 2 \\
\hline Opuntia pilifera & & $\mathrm{X}$ & $\mathrm{X}$ & & & $\mathrm{X}$ & & & & & & & & & & 3 \\
\hline Opuntia hyptiacantha & & $\mathrm{X}$ & $\mathrm{X}$ & & & $\mathrm{X}$ & & & & & & & & & & 3 \\
\hline Opuntia depressa & & & & & & & & & & & & & & & & $*$ \\
\hline Opuntia velutina & & & & & & $\mathrm{X}$ & & & & & & & & & & 1 \\
\hline Opuntia huajuapensis & & & $\mathrm{X}$ & & & $\mathrm{X}$ & & & & & & & & & & 2 \\
\hline Opuntia kleiniae & & & & & & & & & & & & & & & & $*$ \\
\hline Opuntia tehuacana & & & & & & $\mathrm{X}$ & & & & & & & & & & 1 \\
\hline Opuntia decumbens & & & & & & & & & & & & & & & & $*$ \\
\hline Polaskia chichipe\# & & $\#$ & $\#$ & & & $\#$ & & & & & & & & & & $3^{*}$ \\
\hline Tecoma stans & & & $\mathrm{X}$ & & & & & & & & & & & & & 1 \\
\hline Tillandsia dugessi & & & & & & & & & & & & & & & & $*$ \\
\hline Salvia sp. 1 & & & & & & & & & & & & & & & & $*$ \\
\hline Salvia sp. 2 & & & & & & & $\mathrm{X}$ & & & & & & & & & 1 \\
\hline Stenocereus pruinosus & & & $\mathrm{X}$ & & & $\mathrm{X}$ & & $\mathrm{X}$ & $\mathrm{X}$ & & & & $\mathrm{x}$ & & & 5 \\
\hline Stenocereus stellatus & & $\mathrm{X}$ & $\#$ & & & $\#$ & & & & & & & & & & 3 \\
\hline Wigandia urens & & & & & & & & & & & & & & & & $*$ \\
\hline Total & 0 & 11 & 18 & 2 & 2 & 15 & 4 & 6 & 7 & 1 & 4 & 3 & 1 & 0 & 2 & \\
\hline
\end{tabular}




\section{a Cactus forest}

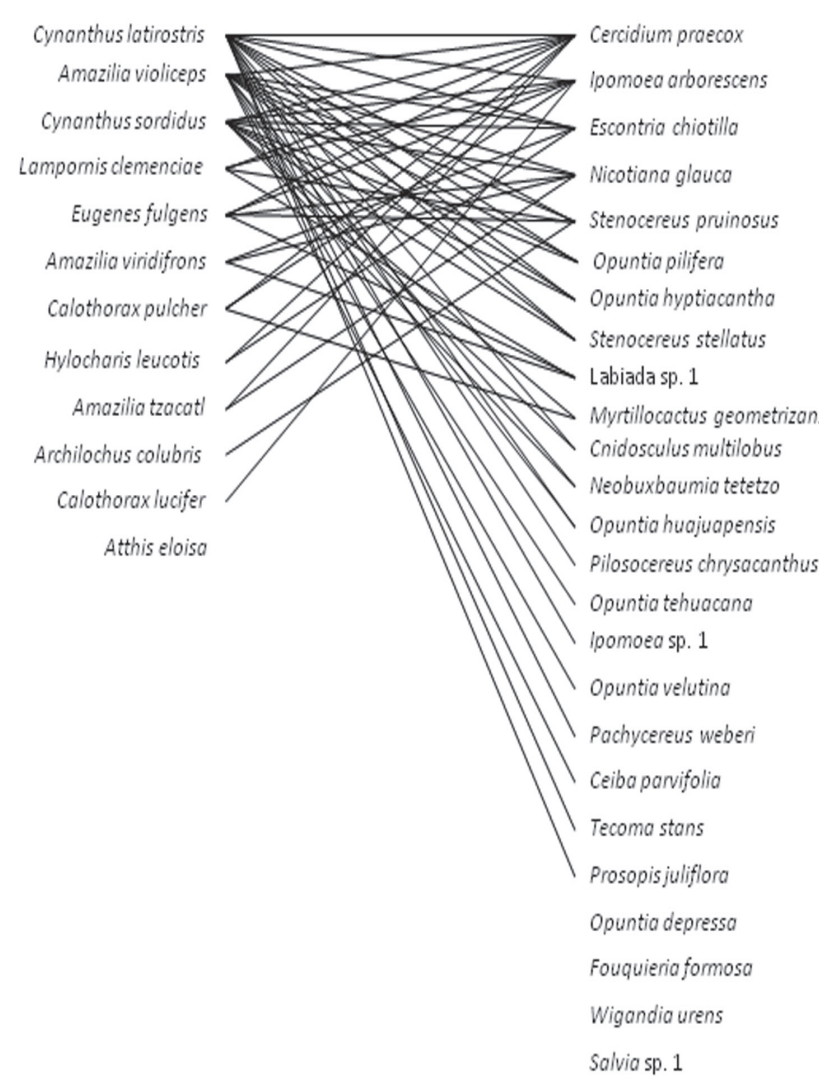

b Arboreal plants of lowlands

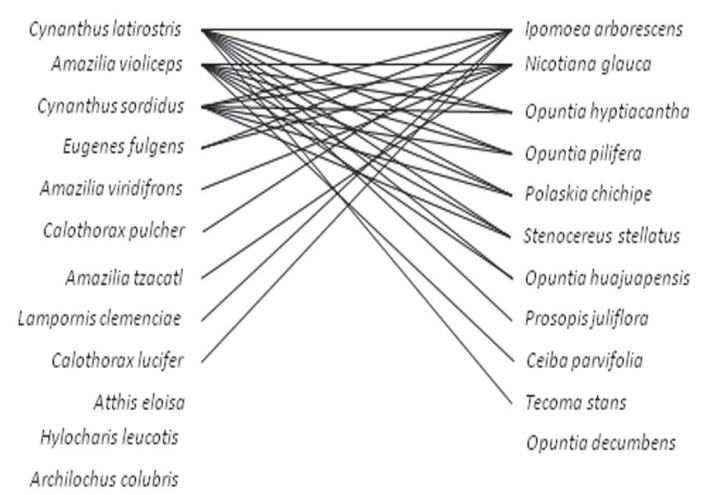

\section{c Perennialspine shrub plants}

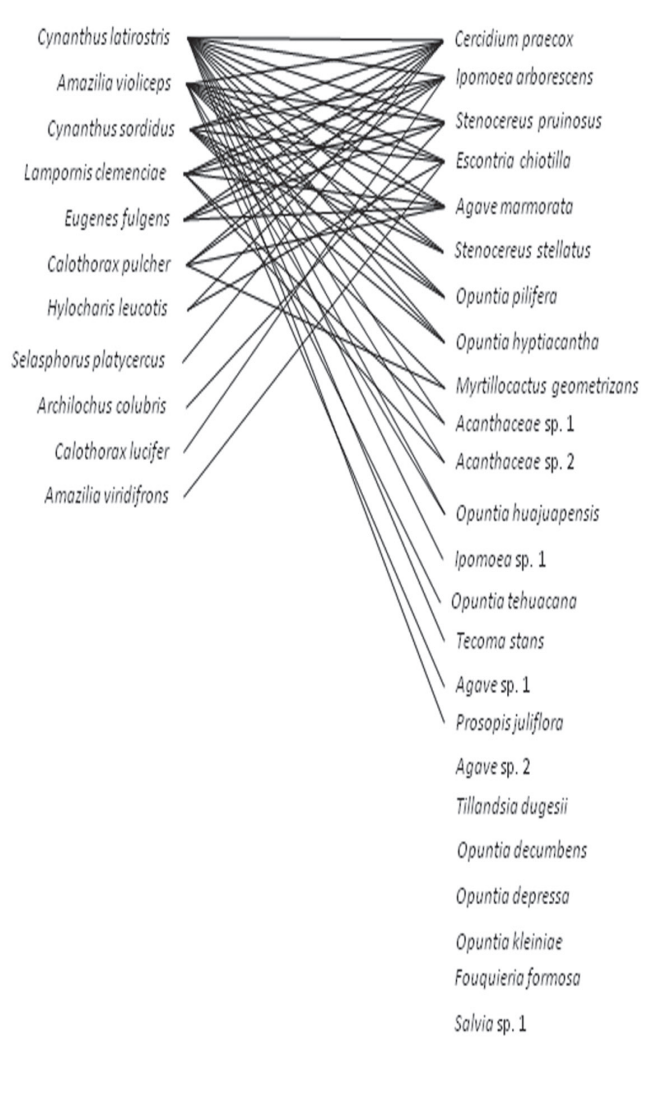

d Perennial unarmed shrub plants

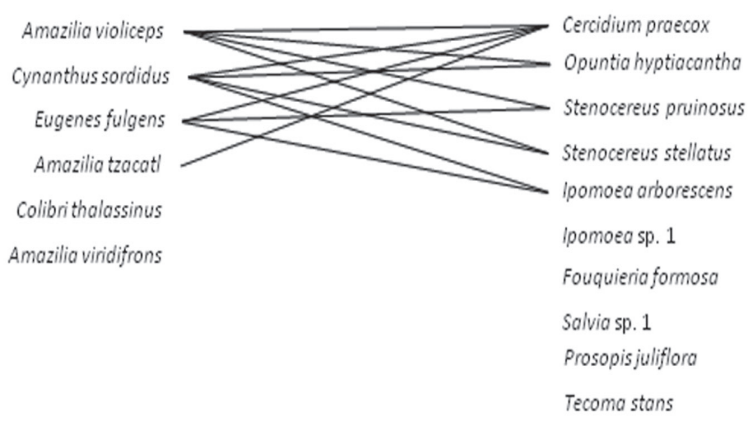

Figure 2. Mutualistic hummingbird-plant networks recorded at 4 plant communities located in the Tehuacán-Cuicatlán Biosphere Reserve, Mexico. In each graph, hummingbirds are on the left side and plants on the right side. Lines between 2 species indicate a relationship registered between both species. 
and (f), the connectance value is similar between plant communities.

The RBTC is a large area representing several climates and vegetation associations (INEGI, 1998a; ValienteBanuet et al., 2000). Thus, hummingbirds, ornithophilous plants, and their interactions are expected to be differentially distributed between plant communities in the RBTC. Our results show that CF had the highest numbers of hummingbird species, plant species, and interactions, while PUSP is the plant community with the lowest numbers for the same variables. Hummingbird richness could be influenced by the diversity of plants which act as food resource, which in turn determines the nectar availability, and along with this also determine the interaction richness. At community level several studies have found a possitive significant relationship between nectar availability and hummingbird relative density (see review of Ortiz-Pulido and Lara, 2011), but few of them show a relationship between plant and hummingbird richness (e.g. Stiles, 1985; Cotton, 2007). However, other variables, such as flower number, nectar-energy availability, or hummingbird inter and intraspecific segregation, affect this relationship (e.g., Ortiz-Pulido and Vargas-Licona, 2008; Ortiz-Pulido and Lara, 2011).

In spite of the difference in species and interactions recorded, the RBTC plant communities are similar in their connectance value (i.e. near to $22 \%$; ranking from 19 to $27 \%$ ). This value is lower than that reported for other sites with hummingbird-plant interaction systems $($ mean $=42 \%)$, but similar to honeyeaters-plant $(21 \%)$ and insect-plant (24\%) systems (Jordano, 1987). The connectance values that we obtained for the RBTC plant communities could have been affected by factors, such as the environment aridness or the conservation level of the study site. From the results of Jordano (1987) it is not clear if the connectance is influenced by aridity or humidy of the environment, precluding any further exploration of the idea. However our results suggest that this is a possibility, with more arid sites having smaller connectance values.

While the connection between connectance values and aridity is not clear, there are some preliminary data related to the relationship between connectance and conservation level. In Costa Rica, data from Wolf et al. (1976) suggest that hummingbird-plant systems located in preserved oak forest have lower connectance value (30\%) than unconserved oak forest sites (64\%) (Jordano 1987). The results of Wolf et al. (1976) agree with theoretical predictions. It has been suggested that network systems that are broken by hazardous conditions will show increasing connectance between the remaining nodes (in this case, species; Montoya et al., 2001). In general, RBTC plant communities are well preserved, with perhaps the exception that the PUSP that showed some degree of grazing presure. Curiously, this is the plant community that showed the highest conectance value in the RBTC. Unfortunately, there are not enough data to determine if the conservation level of a RBTC plant community is related to its connectance.

Our results suggest the existence of certain conservation priorities in terms of hummingbird-plant interaction systems in the RBTC. The main species that should be protected are, for hummingbirds, $C$. latirostris, A. violiceps, $C$. sordidus, and L. clemenciae, and, for plants, C. praecox, I. arborescens, E. chiotilla, and N. glauca, even when not all these species are endemic to Tehuacán-Cuicatlán. Independently of which plant community we consider, these are the more connected species. According to our results, they control the flow of energy, and can be considered as key species in the hummingbird-plant RBTC systems.

In conclusion, RBTC plant communities differ in species richness and number of interactions, but their connectance values are very similar. These values are similar to those reported in other hummingbirdplant interaction systems. A deeper assessment of the hummingbird-plant interactions indicates that in the RBTC plant communities there are key species. To conserve these plant-pollinator interactions, additional work is needed to further understand the biology of these hummingbirds and plants, and to establish the mechanisms that determine the connectance value between hummingbird and plant communities.

\section{Acknowledgments}

We thank Y. Albores, H. Perdomo, A. L. Barillas, A. Rhodes, and M. E. Diazmacip, who collaborated in data collection, S. Arias and J. Garcia for their help to identify plant species, as well as J. B. C. Harris, W. H. Baltosser, R. Díaz, Y. Albores, L. Arregui, and C. Lara, who made useful comments on a previous version of the manuscript. We also thank J. Bravo for the production of the RBTC map. We appreciate the improvements in English usage made by J. Armacost, Jr., through the Association of Field Ornithologists' program of editorial assistance. Many thanks to the Universidad de las Americas-Puebla, A. Cordoba, CECYTE-Puebla, and Quimica y Biologia UDLA-P (2000-2001) student representatives, for their partial financial support to aid field work. We acknowledge the Dirección General de Vida Silvestre (Instituto Nacional de Ecología) for government authorization to plant specimen collection and RBTC directive for the use of their facilities during the fieldwork. This paper was written while ROP received financial support from CONACyT for his sabbatical year. 


\section{Literature cited}

American Ornithologists' Union. 1998. Check-list of North American Birds. 7th Edition. American Ornithologists' Union. Washington, D.C. 829 p.

American Ornithologists' Union. 2009. Check-list of North American Birds. American Ornithologists' Union. www. aou.org/checklist/north/full.php (accessed: 25.II.2009).

Arizmendi, M. C. and F. J. Ornelas. 1990. Hummingbirds and their floral resources in a tropical dry forest in México. Biotropica 22:172-180.

Arizmendi, M. C. and A. Espinosa de los Monteros. 1996. Avifauna de los bosques de cactáceas columnares del valle de Tehuacán-Cuicatlán. Acta Zoológica Mexicana (nueva serie) 67:25-46.

Arizmendi, M. C. and A. Valiente-Banuet. 2006. Aves de la Reserva de la Biosfera Tehuacán-Cuicatlán. UNAM, CONABIO. México, D.F. 162 p.

Arriaga, L., J. Espinoza, C. Aguilar, E. Martínez, L. Gómez and E. Loa (Coordinators). 2000. Regiones terrestres prioritarias de México. Comisión Nacional para el Conocimiento y uso de la Biodiversidad. Mexico. www.conabio.gob.mx/rtp/ fichas/rtp_121.pdf (accessed: 8.I.2002).

Baltosser, W. 1989. Nectar availability and habitat selection by hummingbirds in Guadalupe Canyon. Wilson Bulletin 101:559-578.

Bascompte, J., P. Jordano and J. M. Olesen. 2006. Asymmetric coevolutionary networks facilitate biodiversity maintenance. Science 312:431-433.

Begon, M., C. R. Townsend and J. L. Harper. 2006. Ecology, from individuals to ecosystems. Blackwell, Malden, Massachusetts. $738 \mathrm{p}$.

Binford, L. C. 1989. A distributional survey of the birds of the Mexican State of Oaxaca. Ornithological Monographs 43.

Casas, A., A. Valiente-Vanuet, A. Rojas-Martínez and P. Davila. 1999. Reproductive biology and the process of domestication of the columnar cactus Stenocereus stellatus in Central Mexico. American Journal of Botany 86:534542.

CITES (Convention on International Trade in Endangered Species of the Wild Fauna and Flora). 2000. Apendix I \& II. Convention on international trade in endangered species of the wild fauna and flora. Cambridge, Inglaterra. www.cites. org (accessed March $7^{\text {th }}$ 2005).

Colwell, R. K. 2005. EstimateS: Statistical estimation of species richness and shared species from samples. Version 7.5. http://purl.oclc.org/estimates (accesed: 20.VIII.2009).

Colwell, R. K. and J. L. Coddington. 1994. Estimating terrestrial biodiversity through extrapolation. Philosophical transactions of the Royal Society of London Series B-Biological Sciences 345:101-118.

Cotton, P. A. 2007. Seasonal resource tracking by Amazonian hummingbirds. Ibis 149:135-142.

Díaz-Valenzuela, R. y R. Ortiz-Pulido. 2011. Effects of a snowstorm event on the interactions between plants and hummingbirds: fast recovery of spatio-temporal patterns. Revista Mexicana de Biodiversidad 82:1243-1248.

Emlen, J. T. 1971. Population densities of birds derived from transect counts. Auk 88:323-342.

Forcey, J. M. 2002. Notes on the birds of Central Oaxaca, part II: Columbidae to vireonidae. Huitzil 3:14-27.

Gobierno de México. 1998. Decreto por el que se declara área natural protegida, con carácter de reserva de la biosfera, la región denominada Tehuacán-Cuicatlán ubicada en los estados de Oaxaca y Puebla. Diario Oficial de la Federación, México, D.F., Mexico. September 18th 1998.

Grosselet, M. and T. Burcsu. 2005. Notas sobre las aves de Calpulalpan de Méndez, Oaxaca, Sierra de Juárez, México. Huitzil 6:18-24.

Howell, S. N. G. and S. Webb. 1995. A guide to the birds of Mexico and Northern Central America. Oxford University Press, New York. 851 p.

INE (Instituto Nacional de Ecología). 1999. Áreas Naturales protegidas. Reserva de la Biosfera Tehuacán-Cuicatlán. www.ine.gob.mx (accessed: 07.III.2005).

INEGI (Instituto Nacional de Geografía e Informática). 1998a. Carta climática 1:250,000 Orizaba E14-6. Instituto Nacional de Estadística Geografía e Informática. Aguascalientes, Aguascalientes, México.

INEGI (Instituto Nacional de Geografía e Informática). 1998b. Carta topográfica 1:250,000 Orizaba E14-6. Instituto Nacional de Estadística Geografía e Informática. Aguascalientes, Aguascalientes, México.

Johnsgard, P. A. 1997. The hummingbirds of North America. Smithsonian Institution Press. Washington, D.C. 278 p.

Jordano, P. 1987. Patterns of mutualistic interactions in pollination and seed dispersal: connectance, dependence asymmetries, and coevolution. American naturalist 129:657-677.

Missouri Botanical Garden. 2005. Program w3Tropicos. Missouri Botanical Garden. St. Louis, Missouri, USA. mobot.mobot.org/W3T/Search/vast.html (accessed: 6.V.2005).

Montoya, J. M., R. V. Sole and M. A. Rodríguez. 2001. La arquitectura de la naturaleza. Ecosistemas, revista de ecología y medio ambiente 2:1697-2473.

Oaxaca-Villa, B., A. Casas and A. Valiente-Banuet. 2006. Reproductive biology in wild and silvicultural managed populations of Eschontria chiotilla (Cataceae) in the Tehuacán Valley, Central Mexico. Genetic Resources and Crop Evolution 53:277-287.

Ornelas, J. F. and M. C. Arizmendi. 1995. Altitudinal migration: implications for conservation of avian neotropical migrants in Western México. In Conservation of Neotropical 
migratory birds in México, M. H. Wilson and S. A. Sader (eds.). Mayne Agricultural and Forest Experiment Station, Miscellaneous Publication. Orono, Maine. p. 98-112.

Ornelas, J. F., M. Ordano, A. Hernández, J. C. López, L. Mendoza and Y. Perroni. 2002. Nectar oasis produced by Agave marmorata Roezl. (Agavaceae) lead to spatial and temporal segregation among nectarivores in the Tehuacán Valley, Mexico. Journal of Arid Enviroments 52:37-51.

Ortiz-Pulido, R. and R. Díaz. 2001. Distribución de colibríes en la zona baja del centro de Veracruz, México. Ornitología Neotropical 12:297-317.

Ortiz-Pulido, R. and C. Lara. 2011. Is energy in néctar a good predictor of hummingbird activity at landscape level? Italian Journal of Zoology. DOI 10.1080/11250003.2011.602367

Ortiz-Pulido, R. and G. Vargas-Licona. 2008. Explorando la relación entre registros de colibríes y abundancia de flores con escalamiento espacio-temporal. Ornitología Neotropical 19:473-484.

Ortiz-Pulido, R., J. Bravo-Cadena, V. Martínez-García, D. Reyes, M. E. Mendiola, G. Sánchez and M. Sánchez. 2010. Avifauna de la Reserva de la Biosfera de la Barranca de Metztitlan, Hidalgo, México. Revista Mexicana de Biodiversidad 81:373-391.

Otero-Arnaiz, A., A. Casas, C. Bartolo, E. Pérez-Negrón and A. Valiente-Vanuet. 2003. Evolution of Polaskia chichipe (Cactaceae) under domestication in the Tehuacán valley, Central Mexico: reproductive biology. American Journal of Botany 90:593-602.

Peterson, A. T., G. Escalona-Segura, K. Zyskowski, D. A. Kluza and B. Hernández-Baños. 2003. Avifaunas of two dry forest sites in northern Oaxaca, Mexico. Huitzil 4:3-9.

Sekercioglu, C. H., G. C. Daily and P. R. Ehrlich. 2004. Ecosystem consequences of bird declines. Proceedings of the National Academy of Sciences of the USA 101:1804218047.

Stiles, G. F. 1985. Seasonal patterns and coevolution in the hummingbird-flower community of a Costa Rican subtropical forest. Ornithological Monographs 36.

Tokeshi, M. 1993. Species abundance patterns and community structure. Advances in Ecological Research 24:112-186.

Valiente-Banuet, A., M. A. Arizmendi, A. E. Rojas-Martínez and L. Domínguez-Canseco. 1996. Ecological relationship between columnar cacti and nectar-feeding bats in Mexico. Journal of Tropical Ecology 12:103-119.

Valiente-Banuet, A., A. Rojas-Martínez, A. Casas, M. C. Arizmendi and P. Davila. 1997. Pollination biology of two winter-bloming giant columnar cacti in the Tehuacán Valley, Central Mexico. Journal of Arid Environments 37:331-341.

Valiente-Banuet, A., A. Casas, A. Alcántara, P. Dávila, N. Flores-Hernández, M. C. Arizmendi, J. L. Villaseñor and J. Ortega. 2000. La vegetación del Valle de TehuacánCuicatlán. Boletín de la Sociedad Botánica de México 67:24-74.

Vázquez, L., H. Moya and M. C. Arizmendi. 2009. Avifauna de la selva baja caducifolia de en la cabaña del Rio Sabino, Oaxaca, Mexico. Revista Mexicana de Biodiversidad 80:535-549.

Villada, M. M. 1873. Troquilideos del Valle de México. La Naturaleza (México) 3:339-369.

Villaseñor, J. L., P. Dávila and F. Chiang. 1990. Fitogeografia del Valle de Tehuacán-Cuicatlán. Boletín de la Sociedad Botanica de México 50:135-149.

Walther, B. A. and S. Moran. 1998. Comparative performance of species richness estimation methods. Parasitology 116:395-405.

Walther, B. A. and J. L. Moore. 2005. The concepts of bias, precision and accuracy, and their use in testing the performance of species richness estimators, with a literature review of estimator performance. Ecography 28:815-829.

Wolf, L. L. 1970. The impact of seasonal flowering on the biology of some tropical hummingbirds. Condor 72:1-14.

Wolf, L. K., G. F.Stiles and F. R. Hainsworth. 1976. Ecological Organization of a Tropical, Highland Hummingbird Community. Journal of Animal Ecology 45:349-379. 